\title{
The Importance of Mental Health in the Mexican Public Health System
}

\author{
La importancia de la salud mental en el sistema de salud pública mexicano
}

\author{
Landy Pimentel ${ }^{a}$
}

Received: 10/09/2018, Accepted: 14/12/2018, Published: 05/01/2019

\begin{abstract}
:
The concept of mental illness has been hidden behind a curtain of stigma and dislike for a long time. The magnitude, suffering and burden in terms of disability and costs for individuals, families and society in general are overwhelming and do not correspond with the resources devoted to their research and attention. This document refers the importance of mental health within public health in Mexico. The presence of these mental disorders in society is reaching alarming figures and the forecasts indicate that they will increase. It is vital to highlight three main axes in the development of strategies that seek direct intervention in the population: prevention, hospitalization and social reintegration. It requires a great human and political will along with a great commitment of all health professionals to achieve a real change within the health system in Mexico regarding mental health.
\end{abstract}

Keywords:

mental health, public health, Mexico

Resumen:

El concepto de enfermedad mental se ha ocultado tras una cortina de estigma y disgusto durante mucho tiempo. La magnitud, el sufrimiento y la carga en términos de discapacidad y costos para los individuos, las familias y la sociedad en general son abrumadores y los recursos dedicados a su investigación y atención no son suficientes. Este documento habla sobre la importancia de la salud mental dentro de la salud pública en México. La presencia de estos trastornos mentales en la sociedad está llegando a cifras alarmantes y los pronósticos indican que irán aumentando. Es vital destacar tres ejes principales en el desarrollo de estrategias que buscan la intervención directa en la población: prevención, hospitalización y reinserción social. Requiere una gran voluntad humana y política junto con un gran compromiso de todos los profesionales de la salud para lograr un cambio real dentro del sistema de salud en México con respecto a la salud mental.

\section{Palabras Clave:}

salud mental, salud pública, México

\section{INTRODUCTION}

The World Health Organization (WHO) defines mental health as "a state of well-being in which the individual is aware of his or her own abilities, can face the normal stresses of life, can work productively and fruitfully and is capable to make a contribution to their community". Its importance lies in the fact that it is part of WHO's definition of health: "Health is a state of complete physical, mental and social well-being, and not only the absence of diseases or illnesses". 1
The concept of mental illness has been hidden behind a curtain of stigma and dislike for a long time. The time has come for it to see the light. The magnitude, suffering and burden in terms of disability and costs for individuals, families and society in general are overwhelming. Fortunately, in recent years the world has become a little more considerate of the enormous burden and potential that exists to make progress in the mental health of humanity. ${ }^{2}$ 
The magnitude and impact of mental disorders do not correspond to the resources devoted to their research and attention. The presence of these mental disorders in society is reaching alarming figures ${ }^{3}$ and the forecasts indicate that they will increase. ${ }^{4}$ Between 1990 and 2015, the number of people with depression or anxiety has increased by close to $50 \%$, from 416 million to 615 million. Mental disorders represent $30 \%$ of the global burden in non-fatal diseases, since around $10 \%$ of the world population seems to have a mental disorder ${ }^{5}$, which is alarming, since there are numerous articles that find an association between chronic diseases and mental disorders.

These studies demonstrate an association of some mental disorders in people suffering from chronic diseases such as cancer ${ }^{6}$, cardiovascular disease ${ }^{7}$, diabetes ${ }^{8}$, epilepsy ${ }^{9}$, multiple sclerosis ${ }^{10}$, cerebrovascular disease ${ }^{11}$, Alzheimer's ${ }^{12}$, HIV and AIDS ${ }^{13}$, Parkinson's disease ${ }^{14}$, lupus ${ }^{15}$ and rheumatoid arthritis ${ }^{16}$, impacting even more their life quality.

Currently, global health is in an epidemiological transition, where chronic degenerative diseases have the highest prevalence, so the aforementioned indicates that "Mental health must be a global priority in the field of development and health humanitarian activities, and a priority in all countries", as Arthur Kleinman, Professor of Medical Anthropology and Psychiatry at Harvard University, and world mental health expert said. ${ }^{5,17}$.

However, it is known that mental health is not a priority in public health in many countries of the world, it is always left at the last place of importance, for example, in the distribution of resources. In Latin America, the average coverage for mental health is $1.53 \%$ of total health expenditure. ${ }^{18}$ In this situation, the WHO developed the Evaluation Instrument for Mental Health Systems (EIMHSWHO), which collects essential information to evaluate and strengthen mental health services in a country or region, ${ }^{19}$ with which you can have a better vision of their public policies in mental health and also provide a baseline for tracking changes.

In 1992, the World Federation for Mental Health together with the WHO proposed October 10th as the Mental Health
Day, which is celebrated annually in order to focus the attention on identifying, treating and preventing some emotional disorder or behavior. ${ }^{1}$ The purpose of the date is to raise awareness among the population about the importance of this type of disease and to encourage frank debate on mental disorders and investments in prevention, promotion and treatment services. ${ }^{16}$

This document refers to information generated from the Evaluation Instrument for Mental Health Systems of the World Health Organization (EIMHS-WHO) made in 2011, which is a document that presents a panorama of mental health in Mexico, describing the existing challenges, and presenting a greater contribution to guide public policies to design and develop the changes that are needed. This evaluation instrument of the WHO complies with the regulations and is considered a key tool to introduce improvements in the Mexican National Health System. ${ }^{17}$ The EIMHS-WHO has versions in Spanish, English and French, so today, there are results from 40 countries. The results of this report on the mental health system in Mexico were published in $2011 .{ }^{17}$

\section{MENTAL HEALTH IN MEXICO}

Mexico is a beautiful country, full of culture, with a lot of social and economic diversity, considered by the World Bank as a medium-high income country. ${ }^{19}$ However, the reality is that there is a great inequality of resources for the general population, speaking of essential aspects of life, such as housing, food, education, basic services and health. Historically, the Mexican Health System shows segmentation and fragmentation, which represents challenges in terms of equity in access and quality of health services. Health in Mexico is in charge of some institutions such as the Ministry of Health that serves the public sector, at the same time the Mexican Institute of Social Security (IMSS) provides health services to employees in the private sector, while the Government Workers' Social Security and Services Institute (ISSSTE) attends social and health care needs of those employed by the State, and there is also the Ministry of National Defense (SEDENA) which has its own system of attention for its staff, like Mexican Petroleum (PEMEX) that also has 
its own health system. Everyone else that is not affiliated to the previous institutions has a general health insurance called "Seguro Popular". 20

Now, to focus on the access to mental health services in Mexico, the old paradigm of large asylum psychiatric hospitals still prevails, making impossible to integrate mental health as an important component in the health care system in general. It requires a great human and political will along with a great commitment of all health professionals to achieve a real change within the health system in Mexico regarding mental health. ${ }^{21}$

Public expenditure on health is equivalent to approximately $6.5 \%$ of the country's Gross Domestic Product (GDP), of this total budget allocated to health, only $2 \%$ is oriented to mental health; of this amount, $80 \%$ goes to the operation of psychiatric hospitals, so that the other areas within mental health are left, in a manner of speaking, abandoned and the actions in favor of the promotion, prevention and attention of mental health for the general population are minimal. ${ }^{17}$

Regarding human resources for mental health care in Mexico, the total number of people working in mental health institutions is 10,000 and the rate per 100,000 inhabitants is distributed as shown in Table 1.

Table 1: Human resources for mental health care in Mexico

\begin{tabular}{ll}
\hline Mental health professional & $\begin{array}{l}\text { Number per 100,000 } \\
\text { inhabitants }\end{array}$ \\
\hline Psychiatrist & 1.6 \\
Doctor & 1 \\
Nurse & 3 \\
Psychologist & 1 \\
Social worker & 0.53 \\
Therapist & 0.19 \\
Health professional $/$ & 2 \\
technician & \\
\hline
\end{tabular}

Source: Report on the evaluation of the mental health system in Mexico (EIMHS-WHO), 2011.

These human resources within the health care system are insufficient, they are poorly distributed and most of them are concentrated in psychiatric hospitals. ${ }^{17}$
Regarding psychiatric hospitals, there are 46 of them compared to 13 units of psychiatric hospitalization in general hospitals and 8 residential establishments. Most of these establishments are located in or near large cities, so the figures mentioned above are or should be an alarm to the authorities, since not only there are difficulties in supplying resources, but also, they are limited by geographical barriers. ${ }^{17}$

There are 544 outpatient mental health facilities that offer care to 310 users per 100,000 inhabitants, in contrast to psychiatric hospitals that serve 47 users per 100,000. The majority of patients are adults; the population of children and adolescents is $27 \%$ in outpatient units and $6 \%$ in psychiatric hospitals. These figures are worrisome if we consider that the age of onset of the majority of psychiatric disorders is in the first decades of life; as reported by the National Survey of Psychiatric Epidemiology, where it is stated that $50 \%$ of mental disorders begin before 21 years old. ${ }^{18}$

\section{MENTAL HEALTH IN PRIMARY HEALTH CARE}

The Alma-Ata statement, established that in order to carry out the "Health for all in 2000" policy, it was necessary to develop a specific strategy that remained as Primary Health Care (PHC).$^{19}$

According to the $\mathrm{WHO}$, the $\mathrm{PHC}$ is the essential medical assistance that is accessible to all groups and families of the community through means acceptable to them, with their full participation and at an affordable cost to the community and the country. It is the nucleus of the country's health care

system and an integral part of the general socio-economic development of the society. ${ }^{20}$

Among its proposals, the PHC includes the recognition of local health needs, the strengthening of the first level of care, comprehensive and territorialized medical-sanitary actions, the mobilization of resources and capacities of the groups and community participation. At first, these proposals expand the health work because they are not only devoted to facing the disease ${ }^{20}$, in preventing it and 
promoting health. Also, through the active participation of health professionals who must be in constant training. It would also be prudent to mention the importance of quality undergraduate and graduate mental health students. ${ }^{21}$

According to this, the IESM-OMS mentions that in pre-med school $4 \%$ of the total hours is dedicated to topics related to mental health; the program for nurses, $3 \%$ and in the program for other health personnel, $5 \%$. Eleven percent of doctors working in primary care have received an update training (at least two days) on mental health issues ${ }^{17}$, which is relatively little, since there is a high prevalence of mental disorders that are not diagnosed in a timely manner, and if the diagnosis was made in PHC, it would have many benefits for the user and for health costs, even at a global level.

Primary care centers that have at least one physician (APS) constitute $21 \%$ to $50 \%$ and have evaluation and treatment protocols available for key mental health conditions and carry out at least one referral to a mental health professional per month. A similar percentage carried out at least one activity per year in coordination with other mental health professionals such as psychologists, social workers, etc. ${ }^{19}$ Some of the PHC physicians interacted with a mental health professional at least once during 2008. No contacts were reported with representatives of alternative/traditional medicines ${ }^{17}$, so it would be desirable to have training for health care professionals, specifically for physicians on alternative or natural therapies, for those users for whom western medicine is not functional, this would have benefits regarding costs and well-being of the users.

Currently, mental health must be a priority within public policies that are implemented, providing citizens with quality, low cost or free services. It is important that the population knows about these diseases that are often ignored or unknown by members of communities with difficult access to education.

While the centralist vision about the access to health services remains an axis that guides the efforts of mental health promotion, in little or in nothing at all the system will manage to get into communities where social communication of different institutions devoted to diagnose, prevent and treat mental disorders is, in most cases, non-existent. ${ }^{20}$

Although the panorama seems difficult in recent years, efforts have been redoubled so that the population in general has access to these services, essential for a substantial improvement in their life quality, successful cases such as the State of Hidalgo where the model has been replaced of asylums and obsolete farms in European countries, by care villas and halfway houses, offering people with this type of suffering a complete and human service. The construction of a system that focuses on human rights requires a greater legal precision of the concept of health protection and its scope in terms of obligations and responsibilities, under a unified context and without segmentation regarding the providers, for the three orders of government and the society as a whole. ${ }^{22-}$ 24

It is crucial to highlight three main areas in the development of strategies that seek direct intervention in the population:

1) Prevention: Creating and strengthening communication channels between institutions dedicated to the research and treatment of mental illnesses and the population in general, developing a critical sense among citizens, which allows to demolish long-established beliefs about mental health , that is, that the decentralization of information will play an important role in the coming years, becoming a real challenge for the various government orders since an inclusive vision will allow relevant information on the various existing pathologies to reach the priority groups of the country, aiming at achieving a mental well-being that is defined as a multidimensional construct conformed by positive affection, satisfaction and psychological functioning while wellbeing is explained by functional and psychological components, positive mental health and the combination of these skills to achieve gthem. ${ }^{25}$

2) Hospitalization: People affected by a severe episode of mental illness can be in a state of high vulnerability, including being unable to protect themselves. During these 
episodes, these people can also pose a significant risk to themselves and others. This section not only refers to the rehabilitation of the mental health of the individual, but also to the real restoration of their physical and emotional integrity, relegating the vision of hospital confinement for life to a new paradigm of life quality improvement. ${ }^{26}$

3) Social Reintegration: Mental health does not end with a rehabilitated person, it is a priority of health services to constantly monitor the situation of patients, much of this monitoring is to provide the beneficiaries of these institutions an optimal social reintegration, in which the person can gradually be part of the society again, through several initiatives such as: Community Residences, Day Homes or Social Clubs. With this type of strategy, the person is perceived differently by the society, from being a person out of place to being a functional citizen who gradually control of his/her life. ${ }^{26}$

It is also necessary to point out the imperative improvement in mental health services, the staff designated to attend this group should do it from a quality and continuous improvement perspective in their professional work, thus, constant communication and information shared between the various public and private institutions dedicated to mental health should be a cornerstone in the development of new strategies that will lead to better training plans for the staff in charge of the population's Mental Health. A true global mental health should start from recognizing a community of origins, rights, interests and goals for all people. It is true that we can all have a different concept of what life quality is, but solidarity is that virtuous principle placed above the differences without erasing them, making them instead fertile ground for communication and good practice in favor of humanity's health. ${ }^{27}$

\section{CONCLUSIONS}

The importance of mental health in the public health system is reaffirmed, since it is not only part of the concept of health, but it also affects the style and life quality of all the people and therefore their productivity and the

country's economy. It is also important the great need for a larger budget addressed to mental health in order to have more and better resources for all.

\section{REFERENCES}

1.

\section{2.}

4. López Jaramillo C. Investigación en Salud Mental: Un compromiso de todos. Rev. Colomb. Psiquiat. 2015;44(1):1-2.

5. Organización Mundial de la Salud [Internet]. La inversión en el tratamiento de la depresión y la ansiedad tiene un rendimiento del 400\%. Washington, EEUU. 2016. Available: http://www.who.int/mediacentre/news/releases/2016/depressio n-anxiety-treatment/es/.

6. Landa-Ramírez E, Cárdenas-López G, Andrew-Greer J, Sánchez-Román S, Riveros-Rosas A. Evaluación de la depresión en pacientes con cáncer terminal y su aplicación en el contexto mexicano: Una revisión. Salud Mental 2014;37(5):415-422.

7. Romero CE. Depresión y enfermedad cardiovascular. Rev. Urug. Cardiol. 2007;22(2): 92-109.

8. Zamora-Vega O, Gómez-Díaz RA, Delgado-Solís M, VázquezEstupiñán F, Vargas-Aguayo AM, Wacher-Rodarte NH. Asociación entre depresión e hipoacusia en pacientes con diabetes tipo 2. Rev. Med. Inst. Mex. Seguro Soc. 2016;54(Suppl. 2): S140-S147.

9. Fabelo-Roche JR, Iglesias-Moré S, Louro-Bernal I, GonzálesPal S. Afrontamiento familiar a la epilepsia. Rev. Cubana Salud Pública. 2013;39(3):450-461.

10. Olivares-Pérez T, Nieto-Barco A, Betancort-Montesinos M, Pérez-Martín Y, Hernández-Pérez MA, Barroso-Ribal J. Ansiedad y depresión en la esclerosis múltiple remitenterecidivante: relación con las alteraciones neuropsicológicas y la percepción subjetiva de deterioro cognitivo en pacientes con discapacidad mínima/leve. Rev. Chil. Neuropsicol. 2009;4(1):44-51.

11. Franco López JA. Enfermedad cerebro-vascular y depresión. Rev. Colomb. Psiquiat. 2015 2007; XXXVI (Suppl. 1):92-100.

12. Da Silva-Rodrigues CY, Carvalho Figueiredo PA. Influencia de la depresión en cambios de personalidad del adulto mayor con enfermedad de alzheimer incipiente. Ens. Inv. Psicol. 2017;22(1):103-109.

13. Gaviria AM, Quiceno JM, Vinaccia S, Martínez LA, Otalvaro MC. Estrategias de Afrontamiento y Ansiedad-Depresión en 
Pacientes Diagnosticados con VIH/Sida. Ter. Psicol. 2009;27(1):5-13.

14. Parra N, Fernández J, Martínez Ó. Consecuencias de la enfermedad de Parkinson en la calidad de vida. Rev. Chil. Neuropsicol. 2014;9(1-2):30-35.

15. Zuniga-Zambrano YC, Vásquez R. Trastornos psiquiátricos en pacientes pediátricos con lupus eritematoso sistémico en un hospital de referencia. Rev. Colomb. Psiquiatr. 2014;43(2):7379.

16. Martínez-Cantos JM, Morales-Medina ML, Poma-Cisneros LA Ghia-Coronado CA. Complicaciones psicosociales de los pacientes con artritis reumatoide juvenil. Rev. Cuba Reumatol. 2017;19(3):132-138.

17. Villamil Salcedo V. La salud mental ante los desastres naturales Salud Mental 2014;37(5):363-364

18. National Institute of Mental Health (NIMH). [Internet]. Las enfermedades crónicas y la salud mental: Cómo reconocer y tratar la depresión. 2015. Available: https://www.nimh.nih.gov/health/publications/espanol/lasenfermedades-cronicas-y-la-salud-mental-como-reconocer-ytratar-la-depresion/index.shtml

19. Organización Mundial de la Salud. IESM-OMS Informe sobre sistema de salud mental en México. 2011.

20. Medina-Mora ME, Borges G, Lara C, Benjet C, Blanco J, Fleiz $\mathrm{C}$, et al. Prevalencia de trastornos mentales y uso de servicios: resultados de la Encuesta Nacional de Epidemiología Psiquiátrica en México. Salud Ment. 2003;26(4):1-16

21. Organización Mundial de la Salud [Internet]. Atención primaria Available: http://www.who.int/topics/primary_health_care/es/

22. Anckermann S [Internet]. Atención primaria de salud y los objetivos del milenio. 2012. Avaliable: http://docplayer.es/23943350-Atencion-primaria-de-salud-ylos-objetivos-del-milenio.html

23. Ovidio Muñóz C. Psicología, salud mental y salud pública. CES Psicol. 2014;7(2):184-187.

24. Juan M, Moguel Ancheita A, Valdés Olmedo C, González Pier E, Martínez González G, Barraza Llorens M, et al. Universalidad de los servicios de salud en México. Salud Pública Mex. 2013;55: E3-E64.

25. Barrera Guzmán ML, Flores Galaz MM. Construcción de una Escala de Salud Mental Positiva para Adultos en Población Mexicana. Rev Iberoam Diagn Ev. 2015;1(39):22-33.

26. Barrera PA. La ley de salud mental en Inglaterra. Rev. Chil Neuro-Psiquiat. 2016;54(1):59-66.

27. Lolas F. Salud mental global como bien público: sugerencias para la reflexión ética. Rev. Neuropsiquiatr. 2013;76(3):131136. 